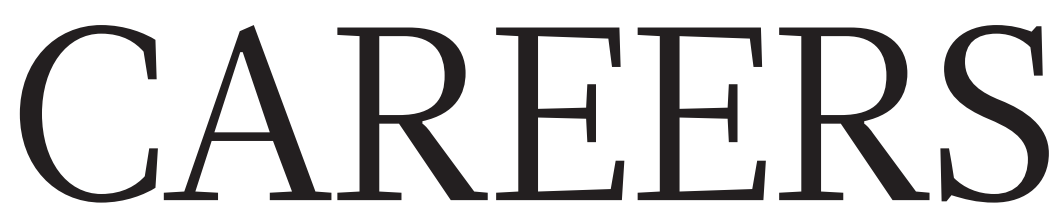

SUPPORT Women-led networks focus on support and empowerment $\mathbf{p . 1 4 5}$
BIOMEDICAL RESEARCH Minority ethnic groups poorly represented in US faculties p.145
SHARE Tell us your career story at naturecareerseditor@nature.com

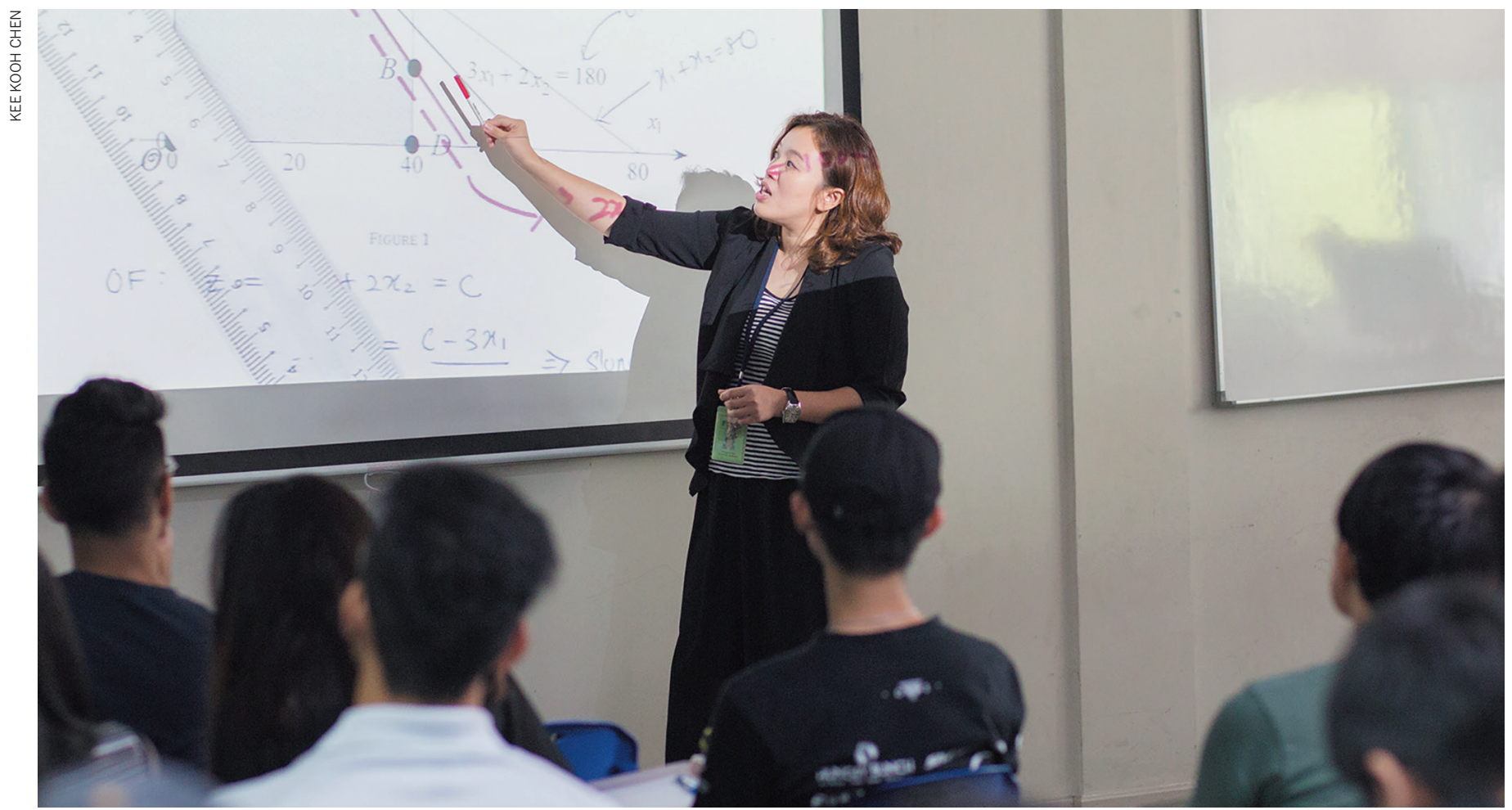

Statistician Weang Kee Ho, who returned to her home country to raise her child with family, teaches at the University of Nottingham Malaysia in Semenyih.

\title{
TRANSITIONS
}

\section{The call of home}

\section{For some who train abroad, returning to their country of birth is a choice, not a fallback.}

\section{BY ELIE DOLGIN}

A run Shukla was in high demand. After a $\mathrm{PhD}$ in Germany and a postdoc in the United States, during which time he cracked the 3D shape of some notoriously elusive membrane proteins and their regulatory molecules, the Indian-born structural biologist began looking for a full-time job.

Colleagues from around the world invited him to apply for permanent positions, many at institutions in Europe and North America that topped global university rankings. But 12 years away from his homeland was long enough. In 2014, Shukla returned with his wife and young son to start a laboratory at the Indian Institute of Technology in Kanpur, not far from where he'd grown up, and where much of his immediate family still lives. Now, he has to travel only 200 kilometres, not
10,000, to visit his parents - who, he notes, get to see and play with their grandson more often.

Shukla knew that the funding opportunities, technical infrastructure and academic acclaim would not be the same in India. But he was determined to put the country on the map for his niche speciality of membrane-protein biology. "My mind was made up," he says. "I had to give it a shot."

Many internationally trained scientists pounce on job opportunities that allow them to stay at top-tier institutions abroad for the long haul - as is evidenced by survey data compiled by Catherine Beaudry, an economist at the Polytechnique Montréal in Canada, and her colleagues. The survey included more than 7,500 young scientists across Africa about the factors influencing their research performance and career development.
The results, published last November, found that among those who had trained away, most would have preferred to stay abroad but could find permanent jobs only back in Africa. "Very few chose to go back home," says Beaudry.

The global academic job market is fiercely competitive, and often the most stable positions lie outside the research powerhouses that dominate best-university lists. In general, those who leave their native countries for a $\mathrm{PhD}$ or postdoc at these types of institution return home out of necessity, not preference.

Shukla is an exception. He's a sought-after scientist who, for reasons of patriotism, family and other personal motivations, took a chance on a career venture back home. He and others who do similar things feel that they can have a bigger societal impact, or a more fulfilling personal life, by returning to their country 
of birth - and in so doing, inspire a new generation of researchers to do the same.

\section{STARTING FROM SCRATCH}

Appu Kumar Singh, who studies ion-channel biology at Columbia University Irving Medical Center in New York City, now considers Shukla a role model. "His scientific accomplishments over the past decade as an independent researcher with limited resources have encouraged postdoctoral fellows like me, who otherwise might not return to India, to do so."

Shukla's first challenge after moving back was finding the resources to continue his work on protein structures. He discussed his plans with many of India's leading scientists, explaining how building the country's expertise in membrane-protein structural biology required access to state-of-the-art cryogenic electron microscopes. "I was told, point blank, that this cannot be done in India," he says. But such responses only spurred him on.

He and colleagues from across the country petitioned the Indian government to invest in the necessary infrastructure and supporting equipment - and last year, the lobbying paid off. In January 2018, the 650-million-rupee (US\$9-million) National Electron CryoMicroscopy Facility opened at the National Centre for Biological Sciences in Bengaluru. The Indian Institute of Science, in the same city, has since procured its own machines for cryoelectron microscopy - and Shukla and his team hope for several similar facilities around the country, particularly in Kanpur.

Shukla has taken advantage of the new microscopes in Bengaluru to visualize distinct conformations of membrane proteins in complex with their activating molecules - the first time this type of research has been done entirely in India, he says. He secured a major research grant from the India Alliance (an initiative co-funded by the Wellcome Trust, a London-based non-profit organization, and India's Department of Biotechnology) as well as a smaller pot of money from the Indian Department of Science and Technology.

As with Shukla, Bilge Demirköz's first few years back in her home country of Turkey were consumed with pressuring the government to invest in infrastructure. Demirköz had spent 14 years training in astroparticle physics in North America and Europe before taking a job at the Middle East Technical University (METU) in Ankara. She could have continued working at CERN, Europe's particle-physics laboratory near Geneva, Switzerland, but she chose to return home - "for idealistic reasons".

Her research productivity initially suffered. Demirköz needed a high-powered - and expensive - piece of equipment called a beamline to continue studying particle interactions. It took a few years to secure funds and build the room-sized, 7-million-lira (US\$1.3-million) machine at the Turkish Atomic Energy Agency's Sarayköy Nuclear Research and Training Center in Ankara. But all the pieces eventually

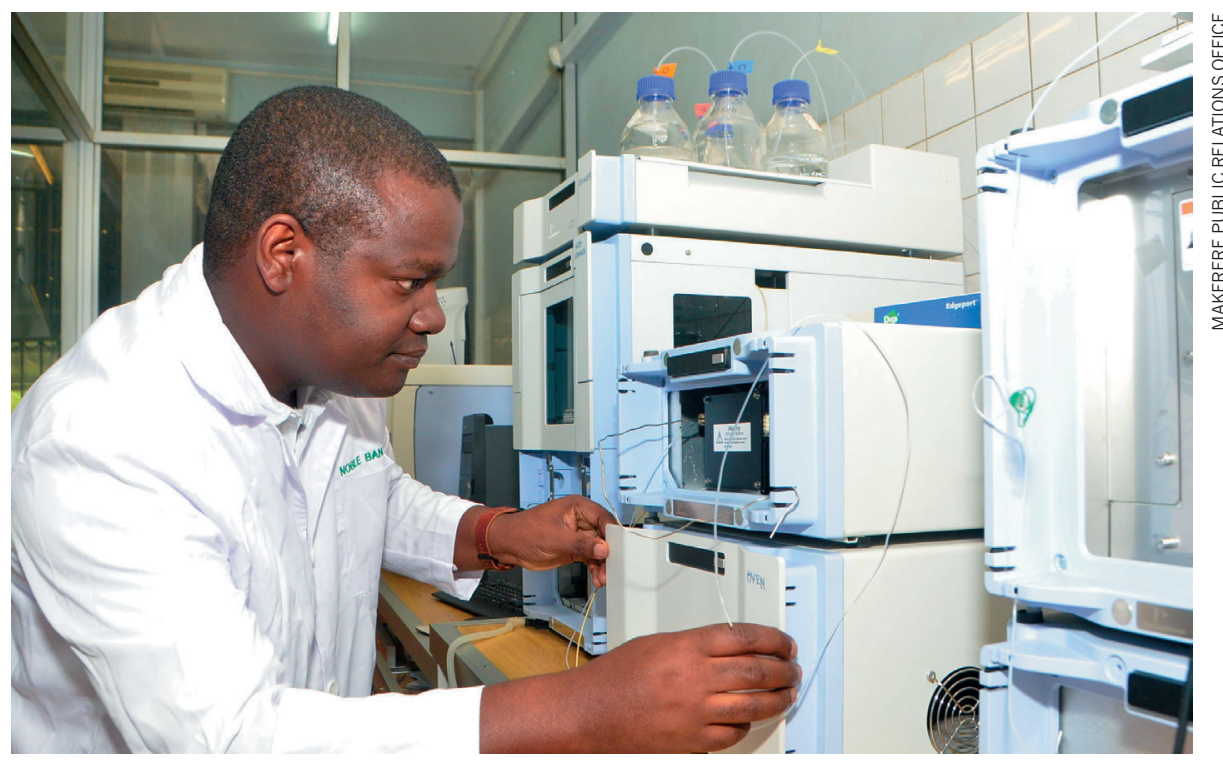

Noble Banadda in his lab at Makerere University in Kampala; he returned to Uganda after his studies.

came together, and in late 2017 Demirköz began preliminary calibration experiments on the METU-Defocusing Beam Line, the first such piece of kit that the country has had. Full operations are expected to begin this year.

Besides facing restrictions on equipment and physical resources, those who choose to set up labs in places not known for scientific prowess might have to get by with limited human resources. Biophysicist Joanna Sułkowska faced this challenge after electing to build her research group at the University of Warsaw in her native Poland. She was drawn by the rapidly improving research landscape in Poland, where, between 2007 and 2015, gross domestic spending on research and development (R\&D) had nearly doubled, creating ample funding opportunities. But it's harder to hire good postdocs there than in the United States, where she trained, she says.

Still, the fact that Sułkowska chose to return reflects a shifting global scientific reality, one in which academic dominance - and the availability of funding and resources - is rapidly moving away from the conventional hotspots of the West.

In China, for example, spending on $R \& D$, when corrected for purchasing power, was projected to eclipse that of the United States by the end of 2018. Returning to a Chinese university today is less of a fallback, says Johannes Geffers, an occupational psychologist at the Institute for Innovation and Technology in Berlin, who, together with Beaudry and other members of the GYA, studied the career trajectories of young scientists from several Asian countries.

"They know the balance is changing to the East," Geffers says, "and coming back is becoming more of an option."

\section{ADJUSTMENT PERIOD}

Malaysian statistician Weang Kee Ho is one person who took that option. She had earned her bachelor's and graduate degrees in the United Kingdom and was completing a second postdoc there when, on holiday in Kuala Lumpur, she visited several potential employers, including the University of Nottingham Malaysia in Semenyih, where she now works, and Cancer Research Malaysia in Subang Jaya, with which she's also affiliated.

When that informal university visit led to an official job offer, Ho consulted her former $\mathrm{PhD}$ adviser, who is British, on whether moving back to Malaysia would be a wise move professionally, and he was supportive. "That had a huge impact on my decision," Ho says. What sealed the deal was that Ho became pregnant. "For a child, being able to grow up having grandparents and relatives around is the best thing," she says. She returned to Malaysia in May 2013, and her son was born four months later.

Ho says that being back was challenging. Resources were limited. At the University of Cambridge, UK, she had had the opportunity to study genetic variants linked to heart disease in data sets drawn from tens of thousands of individuals. In Malaysia, she had to settle for sample sizes that were much smaller, which limited possible analyses. But she could now work on health issues affecting her own country's population. For example, she helped to establish models of breast-cancer risk factors among women in Malaysia, where incidence of the disease is projected to rise by $50 \%$ within the decade. "That means a lot to me," Ho says.

For viro-immunologist Sandra López Vergès, the challenges of starting her own group at the Gorgas Memorial Institute for Health Studies in Panama City after 14 years abroad centred more on amassing basic lab staples. She moved back to Panama after graduate studies in France and a postdoc in the United States - mainly, she says, to be closer to family and to the country's immense tropical ecosystems.

López Vergès had listed the pros and cons of returning, and had discussed her plans with mentors, fellow postdocs and family members. She had also sounded out leaders of 
Panamanian research institutes in her field to ensure that there would be adequate opportunities there. On top of that, she'd secured a three-year repatriation grant to make certain that, scientifically, she could hit the ground running - and she advises others thinking of returning home to do the same. "Contact researchers who have already come back, so they can help you with their experience and even give advice with the grant application."

López Vergès still faces bureaucratic challenges, however. Because federal rules require all purchases to go through Panamanian distributors, with pre-audits of all her spending choices, it took her about 18 months to secure a flow cytometer for her research into the immune system. It also takes months for her to receive reagents and other basic lab essentials.

Those delays cost López Vergès academically. In 2016, a group from France and Gabon published a detailed analysis of natural killer cells in people infected with the dengue and chikungunya viruses - scooping López Vergès, who had similar but incomplete data. "That was really frustrating," says López Vergès, who has since finished her study, although her find-
"For a child, being able to grow up having grandparents and relatives around is the best thing."
Kirkland, Washington.

Returning to the United States was not a move he took lightly. "It was a really hard decision for me to say, 'OK, I'm leaving Colombia again,' Bernal says. Still, he hasn't completely severed his academic ties to Colombia. He maintains an adjunct position at the University of Antioquia in Medellín, and works in the evenings and at weekends with collaborators back home to advance his research. "I might not be able to live in Colombia right now," says Bernal, "but I want to keep my connections."

\section{ENGINEERING OPPORTUNITIES}

Maintaining connections internationally has been key to the success of Ugandan-born bioprocessing engineer Noble Banadda, although he does so from his home base at Makerere University in Kampala. After a PhD at the Catholic University of Leuven in Belgium, followed by a postdoc at the Massachusetts Institute of Technology (MIT) in Cambridge, Banadda received job offers from large chemical companies in Germany and New Jersey. Then came more recruitment efforts from universities across the United States.

But Banadda chose to stick with his academic post in East Africa - becoming, at 37 , the youngest fellow to be inducted into the Uganda National Academy of Sciences. "I've established myself here," he says.

Each summer, however, Banadda returns to the United States as a visiting professor at MIT or at one of the many institutions that had tried to recruit him and at which he'd accepted an adjunct position instead. And in December 2018, he spent a few weeks in the United Kingdom, developing biopackaging materials from banana leaves at the University of Cambridge.

These stints as an academic-in-residence abroad have allowed Banadda to "stay relevant in the international research world", he says, while at the same time working on low-tech inventions such as a multipurpose tractor that can till land for planting, pump water for irrigation and harvest maize at an affordable cost for small-scale farmers in East Africa.

"I can't even publish that," he says, "but it's a solution that changes people's lives." -

For some, however, returning home doesn't work out. Colombian-born ultrasound scientist Miguel Bernal moved back to Medellín after more than a decade away - first as a PhD student at the Mayo Clinic in Rochester, Minnesota, and then as a post$\mathrm{doc}$ at the Langevin Institute in Paris. $\mathrm{He}$ secured a prestigious scholarship from the Colombian government, and in 2015 started working at the Pontifical Bolivarian University, Medellín, where he created a material for testing medical-imaging technologies.

Hoping to land a permanent position, he approached the leaders of five universities in Medellín, but met dead ends. Dejected, he flew north, first for a five-month Fulbright scholarship at the Mayo Clinic, then for an R\&D post at an ultrasound manufacturer based in

\section{GENDER GAP}

\section{How networks differ}

Family responsibilities and other societal barriers keep female leaders from joining male-led networks that offer professional benefits, finds a study. The gap, authors say, could partly account for gender inequality in the workplace, because professional networks that are formed by and composed of men tend to offer information about professional opportunities and insight (E. Greguletz et al. Hum. Relations http:// doi.org/cx3r; 2018). But the authors, who interviewed 37 female business leaders in Germany from 2015 to 2016, say that female-run professional networks also provide significant, yet different, benefits. "If success is solely defined as furthering one's career, men's networks have been shown to be more successful," says co-author Marjo-Riitta Diehl, who studies organizational behaviour at the EBS Business School in Oestrich-Winkel, Germany. But, she notes, women's networking activity might be undervalued. "The relationships that women form are equally important, but in a different manner," she says. The study notes that female-led networks offer an empowering sense of reciprocity to their members. Women tend to seek emotional and social support from their networks, it finds, whereas men aim for promotions and job opportunities.

\section{BIOMEDICAL FACULTIES}

\section{Ethnic mix still poor}

Minority ethnic groups, including African Americans and Hispanics, continue to be under-represented in biomedical-research faculties at US medical schools, according to a study last year (L. C. Meyers et al. PLoS ONE 13, e0190606; 2018). Based on publicly available national data, the study of under-represented minority populations finds that their numbers and proportions rose steadily from 2000 to 2013 at every academic career stage except the final step, from postdoctoral researcher to tenure-track faculty member. Minority ethnic and racial groups comprise just 3-4\% of full-time medical-school faculty members. "We should be seeing increases in under-represented minorities in faculty positions at top-tier research institutions," says study co-author Roger Chalkley, a senior associate dean at Vanderbilt University School of Medicine in Nashville, Tennessee. "But they are not getting those jobs." Chalkley says that he and his co-authors cannot yet identify barriers. He theorizes that reluctance to apply for those positions, along with discrimination, might play a part. 


\section{CORRECTION}

The Careers feature 'The call of home' (Nature 566, 143-145; 2019) erroneously stated that the study of scientists across Africa was conducted by the Global Young Academy. The survey was in fact co-led by Catherine Beaudry at Canada's Polytechnique Montréal. 